\title{
Integrating Design Heuristics into Your Classroom
}

\section{Dr. Keelin Siomha Leahy, University of Limerick}

Keelin Leahy is a lecturer of Technology Education at the University of Limerick. Keelin received her PhD from the University of Limerick in 2009, which focused on Design approaches in second level education. Keelin's main research interests include approaches for the development of creativity and design based activities and pedagogy in second level education. Keelin lectures in the areas of Design for Teachers, 3D CAD Modelling, Wood Design and Technology, Wood Processing Practice and Safety.

\section{Dr. Seda Yilmaz, Iowa State University}

Dr. Yilmaz is an Associate Professor of Industrial Design. She teaches design studios and lecture courses on developing creativity and research skills. Her current research focuses on identifying impacts of different factors on ideation of designers and engineers, developing instructional materials for design ideation, and foundations of innovation. She often conducts workshops on design thinking to a diverse range of groups including student and professional engineers and faculty member from different universities. She received her PhD degree in Design Science in 2010 from University of Michigan. She is also a faculty in Human Computer Interaction Graduate Program and the ISU Site Director for Center for e-Design.

\section{Colleen Seifert, University of Michigan}

Colleen M. Seifert is an Arthur F. Thurnau Professor in the Department of Psychology at the University of Michigan, where she has taught since 1988. She received her Ph.D. in Cognitive Science and psychology at Yale University. She was an ASEE postdoctoral fellow at the University of California - San Diego and the Navy Personnel Research Development Center. Her research interests center on learning, memory, and creativity.

\section{Dr. Shanna R. Daly, University of Michigan}

Shanna Daly is an Assistant Professor of Mechanical Engineering at the University of Michigan. She has a B.E. in Chemical Engineering from the University of Dayton (2003) and a Ph.D. in Engineering Education from Purdue University (2008). Her research focuses on strategies for design innovations through divergent and convergent thinking as well as through deep needs and community assessments using design ethnography, and translating those strategies to design tools and education. She teaches design and entrepreneurship courses at the undergraduate and graduate levels, focusing on front-end design processes. 


\title{
Integrating Design Heuristics into Engineering Classrooms
}

\begin{abstract}
While successful concept generation is essential for innovative solutions, engineering students often receive limited instruction about how to accomplish it. Design Heuristics have been shown to facilitate concept generation by guiding students to explore multiple concepts in the solution space. In this study, we investigated how four instructors integrated Design Heuristics into their own engineering design courses. We conducted interviews with instructors about their preparations, approaches, and classroom experiences while integrating the Design Heuristics pedagogy into their courses for the first time. The findings revealed that both novice and experienced instructors reported few challenges in lesson preparation and implementation, and positive impacts on students' idea generation outcomes. These experiences offer guidelines to support other instructors in their adoption of the Design Heuristics tool for student idea generation.
\end{abstract}

\section{Introduction}

While the importance of concept generation in developing innovative solutions has been demonstrated $^{1-7}$, students often struggle to generate creative solutions ${ }^{8-11}$. Engineering educators lack techniques to support instruction on concept generation ${ }^{12-15}$, and pedagogical strategies for innovative idea generation can raise challenges for engineering educators. New strategies for teaching creative idea generation could play a significant role in building innovation skills in engineers, and help to prepare them for professional practice.

Conceptual design is a critical stage in the design process for a product, system or service ${ }^{16}$. The conceptual phase of design includes initial generation of multiple ideas, which are then evaluated using the problem specifications ${ }^{16}$. During the early concept generation phase, students often become fixated on their initial concepts, and may prematurely begin evaluation ${ }^{10,17,18}$. This results in a need for pedagogical strategies to aid students in enriching their conceptual design phase. Instructors must understand how concepts are generated, and how tools can facilitate the exploration of potential design solutions.

One challenge in teaching concept generation in engineering is that techniques proven helpful in concept generation may be slow to be adopted by instructors ${ }^{19-21}$. Thus, in this study, we explored how an empirically-validated idea generation tool, Design Heuristics, was integrated by engineering instructors in their courses. The goal of this research was to investigate successes and challenges faced by instructors so as to discover ways to support the incorporation of Design Heuristics in pedagogy. The results will inform about how to teach Design Heuristics successfully within existing engineering classes to improve student idea generation outcomes.

\section{Background}

\section{Tools for idea generation}


There are a variety of idea generation tools available for concept generation ${ }^{1,2}$, including analogical thinking ${ }^{22}$, brainstorming ${ }^{23}$, conceptual combination ${ }^{24}$, Design Heuristics ${ }^{1,2,25-28}$, lateral thinking ${ }^{29}$, morphological analysis ${ }^{30,31}$, SCAMPER $^{32}$, Synectics $^{33}$, and TRIZ ${ }^{34,35}$. These tools vary in focus and specificity. For example, brainstorming recommends general guidelines, including 'suggest many ideas', and 'do not evaluate ideas', but provides little direction about how to actually generate ideas. Other methods, such as SCAMPER, provide more specific prompts on how ideas can be formed by "combining" or "modifying" existing ideas. Some tools, such as Synectics and TRIZ, require extensive training and practice to become skilled in their use. $^{45}$ In addition, only a few of these ideation tools have been empirically validated or empirically tested for their success in concept generation ${ }^{7,36}$. One tool, Design Heuristics, is based on evidence from thousands of design concepts, and has been demonstrated to support student exploration of design solution spaces ${ }^{7,28,37-41}$.

\section{Design Heuristics}

Design Heuristics serve as "cognitive shortcuts" for exploring the space of possible design solutions. They are intended to support engineering designers by guiding designers towards nonobvious ideas, and helping them generate multiple concepts to consider. They are also intended to assist designers when they become fixated by helping to generate more, and more different, concepts $^{1,2,37,42}$.

The Design Heuristics tool is comprised of 77 cards used to augment ideation. Each card includes a specific design prompt, along with a graphical representation and descriptive text. On the reverse of each card, two existing product examples are provided where the specific heuristic is evident. An example of a Design Heuristic is, Apply an existing mechanism in a new way. This prompts the designer to use an existing product or component to function differently in a new concept. For example, an engineer could take an existing mechanism like a bicycle and apply it as a power source for a generator. This one Design Heuristic can be applied repeatedly to generate other concepts (e.g., using a water bottle to squirt water and turn a wheel). Other Design Heuristics (e.g. 'Change direction of access') can be added and combined (placing the pedals in the air with the rider beneath) to produce a variety of novel ideas. The many prompts available in the 77 Design Heuristics ensure a large supply of possible directions to pursue.

This set of Design Heuristics were identified in empirical studies including 1) behavioral studies of student and expert conceptual designs; 2) a case study of a long-term project by a professional designer; and 3) analyses of award-winning products. Design Heuristics were identified through analysis of sketches showing transitions from one concept to another over time ${ }^{39}$. Each heuristic was observed multiple design concepts, by multiple engineers and designers, and in solutions for multiple design problems. Accumulating evidence across studies resulted in 77 unique Design Heuristics applicable to a wide variety of products. Past research has demonstrated the effectiveness of the Design Heuristics tool in facilitating concept generation for engineering students $1,2,6,7,37,38,42,43$ and professionals ${ }^{39,40}$.

\section{Research Method}


This paper investigated how engineering educators integrated Design Heuristics into a concept generation lesson as part of an engineering design class. To gather evidence of how instructors implement Design Heuristics into their courses, four instructors' classroom sessions were videorecorded as they were introducing the heuristics to students.

\section{Participants}

Participants included four engineering instructors at two US institutions: a large mid-western research university and a small, private liberal arts university. All four courses were required courses within mechanical engineering curricula.

Past teaching experience varied among the participants (Table 1): two instructors had extensive teaching experience, and it was the first-time teaching independent courses for two others.

Table 1: Participant background

\begin{tabular}{|l|l|l|}
\hline Ref: & Instructor Position: & Teaching experience \& expertise: \\
\hline A & Assistant Professor & $\begin{array}{l}\text { Multidisciplinary Engineering Design, } \\
\text { Electrical Engineering }\end{array}$ \\
\hline B & Instructor & $\begin{array}{l}\text { Multidisciplinary Engineering Design, } \\
\text { Computer Engineering }\end{array}$ \\
\hline C & Graduate Student Teaching Assistant & $\begin{array}{l}\text { First year of teaching Mechanical } \\
\text { Engineering }\end{array}$ \\
\hline D & Graduate Student Teaching Assistant & $\begin{array}{l}\text { First year of teaching Industrial } \\
\text { Operations Engineering. }\end{array}$ \\
\hline
\end{tabular}

The dynamics among the instructors should be noted. Instructor A and Instructor B were on an instructional team together, teaching the same course in two different sections; Instructor A teaches the lecture and Instructor B teaches the lab session. Instructor C and Instructor D were also on an instructional team together with ten colleagues. Instructor $C$ and $D$ taught the same course in two different sections; Instructor C taught one lab session and Instructor D taught another lab session.

\section{Design Heuristic lesson resources}

Each instructor had access to Design Heuristics resources on a public website ${ }^{24}$, which included a 28-minute lesson video, lesson slides in PowerPoint (PPT) (Figure 1) and links to research articles. Each instructor was also provided with multiple decks of Design Heuristic cards (Figure 2). It was up to each instructor to choose whether and how to use these materials. No additional information was provided to the instructors regarding how to implement the lessons in their classes. 

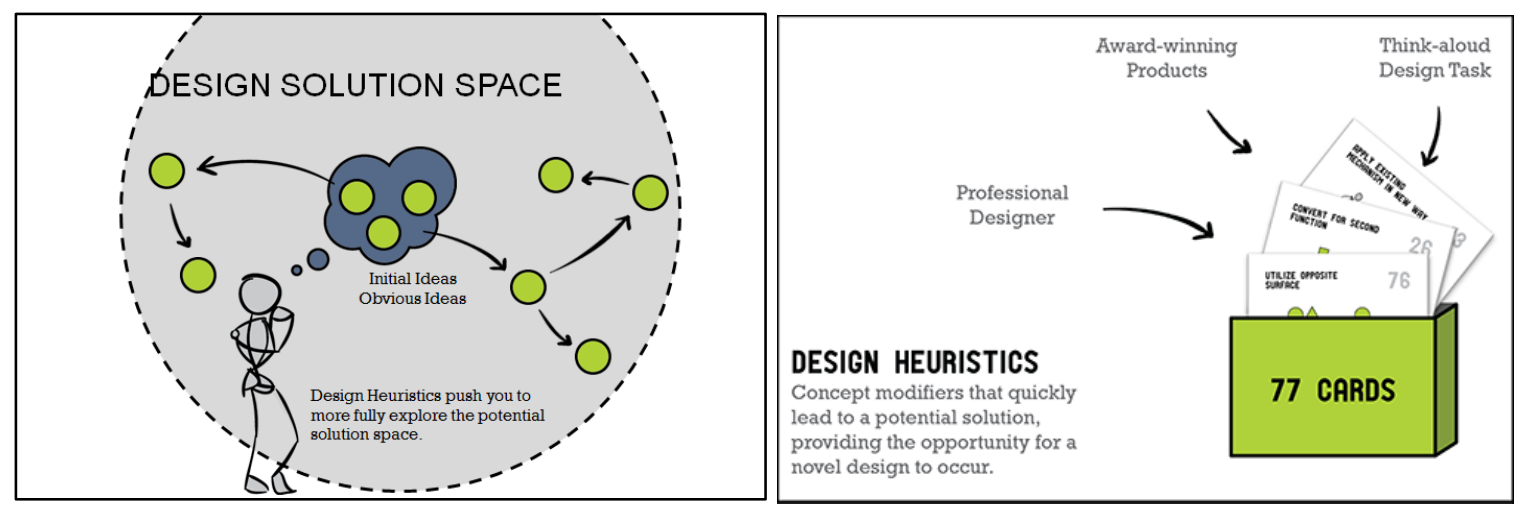

Figure 1: Examples of Design Heuristics slides
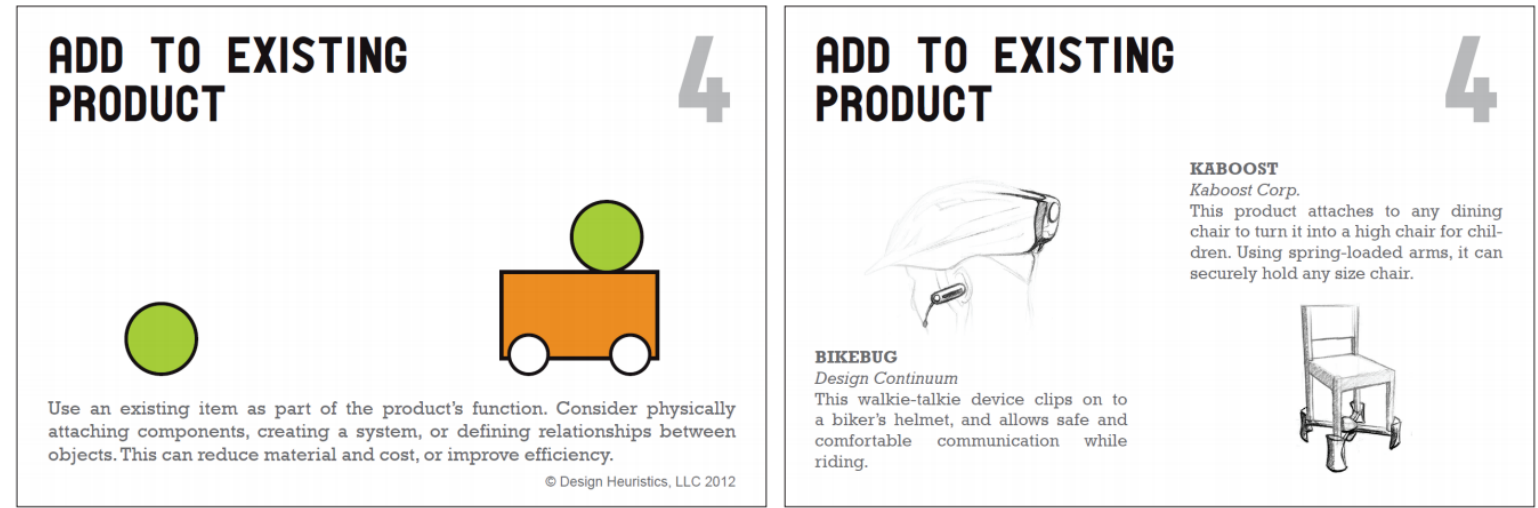

Figure 2: Example of a Design Heuristic card (front and back)

In the 28-minute lesson video, the narrator describes the "why" and "how" of using Design Heuristics to generate ideas. The video provides a "how to" demonstration for classroom instruction using "77 Cards: Design Heuristics for Inspiring Ideas." In addition, the video shows a question and answer exchange, and idea sharing within a group of students as they practice using Design Heuristics.

\section{Data collection and analysis}

Each instructor provided their course documentation and video recording. Each instructor was also individually interviewed about their experiences. These interviews ranged between 30 to 60 minutes. The semi-structured interview protocol focused on following questions:

- What preparation did you go through for this activity? Individually? With the others?

- Can you reflect on the experience of introducing the design heuristics to your course? What went well? What didn't go as well? What would you do differently?

- What changes did you make between the first and second class session? Why did you make these changes? [note the difference in time and depth of examples/application between the two]

- How did the students react to this idea generation method?

- What are the implications for introducing idea generation relatively late in the semester, after their core design already appears to be set? How much innovation happened on the functional component level? Did any of this innovation trickle up to the overall design approach? 
- What was the biggest challenge introducing a new idea generation method to your students? The biggest success? [especially elicit examples of students that did and did not react well]

The video recordings and interviews were transcribed and analyzed to determine similarities and differences across instructors. We used an inductive analysis approach to identify trends in the data. This involved rounds of open, axial, and selective coding to explore the data for similarities and differences ${ }^{44}$. No student data were recorded or included in this study.

\section{Findings}

The main findings for the instructors' experiences are reported in 7 categories grouped according to timing: 1) Before DH session (interview), 2) During DH session (video recording), and 3) Reflection after DH session (interview) (Table 2).

Table 2: Capturing the findings

\begin{tabular}{|l|l|l|}
\hline Time & Category & Description \\
\hline $\begin{array}{l}\text { 1. Before DH } \\
\text { session }\end{array}$ & $\begin{array}{l}\text { A. Past experience } \\
\text { teaching DH }\end{array}$ & $\begin{array}{l}\text { Instructors' experience before, during and } \\
\text { further the DH session / Future plans for using } \\
\text { them in their classrooms }\end{array}$ \\
\cline { 2 - 3 } & B. Preparations & $\begin{array}{l}\text { Meetings, planning, and discussions regarding } \\
\text { the prep work the instructors did. The uses of the } \\
\text { DH website resources are also recorded. } \\
\text { Approaches and other design tasks in the design } \\
\text { process. }\end{array}$ \\
\hline $\begin{array}{l}\text { 2. During DH } \\
\text { session }\end{array}$ & $\begin{array}{l}\text { A. Pedagogical } \\
\text { approaches }\end{array}$ & $\begin{array}{l}\text { The placement of the DH tool with respect to } \\
\text { other activities. } \\
\text { The pedagogical approaches related to } \\
\text { affirmation or use of praise, or thinking } \\
\text { approaches. }\end{array}$ \\
\cline { 2 - 3 } & B. Introduction to DH & $\begin{array}{l}\text { How instructors introduced the DH tool during } \\
\text { their lesson }\end{array}$ \\
\cline { 2 - 3 } & C. Challenges & The challenges experienced by instructors \\
\hline \multirow{2}{*}{$\begin{array}{l}\text { 3. Reflection } \\
\text { session }\end{array}$} & $\begin{array}{l}\text { A. How DH transformed } \\
\text { their instruction } \\
\text { (pedagogical style) }\end{array}$ & $\begin{array}{l}\text { Highlights of instructor aims for going forward } \\
\text { with future instruction and improvements to DH } \\
\text { lessons }\end{array}$ \\
\cline { 2 - 3 } & $\begin{array}{l}\text { B. Change in student } \\
\text { activity }\end{array}$ & $\begin{array}{l}\text { Instructors describing the change in student } \\
\text { activity after they were introduced to DH }\end{array}$ \\
\hline
\end{tabular}

\section{Before DH session}

A. Experience teaching Design Heuristics

All the instructors were familiar with the Design Heuristics tool. An overview of the instructors experience in the context of the Design Heuristic tool is outlined in Table 3.

Table 3: Experience with Design Heuristic tool 


\begin{tabular}{|l|l|}
\hline Instructors & Experience with Design Heuristics \\
\hline Instructors & Attended a Design Heuristics workshop. Implemented Design Heuristics in \\
A \& B & previous classes. \\
\hline $\begin{array}{l}\text { Instructors } \\
\text { C \& D }\end{array}$ & $\begin{array}{l}\text { Used Design Heuristics as an undergraduate in class in addition to practicing } \\
\text { with them independently. First time teaching a class using the Design Heuristic } \\
\text { cards. }\end{array}$ \\
\hline
\end{tabular}

During the interview, the instructors provided information based on their own experiences with the heuristics and the experiences of their students. They highlighted that their students did not have much prior exposure to design: "They've not had a lot of design experience" (Instructor A), and "In truth they don't have very many opportunities to design prior to their senior design projects. You don't get many chances to practice" (Instructor B). Instructor B also commented on students' approaches to design in a teamwork setting: "I'd be surprised if there was a lot of sharing of ideas in the classroom space. There might have been time for the teams to get together and work but I doubt that was shared outside the teams."

The instructors outlined a range of idea generation tools and approaches used by their students, including priming, decision-making matrixes, and mind maps. For example, Instructor $\mathrm{C}$ highlighted: "We ask them to use specifically mind maps and that's how they generate their first concept and then moving through these selection matrixes and other forums to narrow down ideas." Instructor D explained: "There were a lot of design selection matrices, sketches, CADs. The way we do it was we broke... We encourage the students to break the problem, which is a competition, down into several requirements that they had to meet. Then, you have to design selection matrices to ... Or brainstorm and ... Mostly brainstorm, to come up with four or five different concepts and use the design selection matrix to select 1. That was the general way we went about doing it... we talked about morphological analysis a little bit as well, kind of along the same lines with heuristics."

The implementation of the Design Heuristics cards varied among instructors. Instructor C described the importance of allowing students to experience the heuristic tool use during their instruction; "Yeah familiarity with the cards and actually using them on a project I think is very useful and not so much just introducing them and saying these are available but actually using them." One instructor's prior experience highlights the advantage of using the heuristic cards to overcome idea exhaustion and look for more than the required number of concepts. Instructor D reported: "Okay, I came up with concept one, two, three, and four, but I don't think this is enough and I'm stuck. Then I'll just go to the website and look through the cards, or maybe listen to the lectures and see if anything sparks. Sometimes it does and sometimes it doesn't, which is okay. I think it's better than just being stuck and just saying, 'Whatever, four is enough'.,

\section{B. Preparations}

Each instructor provided course documentation for the Design Heuristics lesson implementation. From the course documentation, an abridged semester schedule was extracted (Table 4). The integration of Design Heuristics into the curriculum ranged from a planned semester schedule to uncertainty over alternate strategies. For example, Instructor $\mathrm{C}$ stated: "We knew we wanted to incorporate it. We just didn't know when and what was more important, whether to talk on mind 
maps or to do design heuristics." The level of preparation carried out by the four instructors included meetings, discussions with other instructors, and individual planning. In both institutions, there were established weekly course meetings. During these meetings, discussions took place about where to include the Design Heuristics tool. The schedule overview in Table 4 shows where the Design Heuristic tool placement occurred in the design process. Instructors A and B placed it during initial concept development in Week 6, after design problem specifications were identified. Instructors C and D used the Design Heuristic tool in Week 4, though later in the design process, to refine concepts after feedback and prior to final proof of concept. Instructor D commented that their implementation of the Design Heuristics tool occurred too late: "I think it is still a little too late because they were already towards the end of their concept generation stage."

Table 4: Semester schedule

\begin{tabular}{|c|c|c|}
\hline & $\begin{array}{l}\text { Instructor A } \\
\text { Instructor B }\end{array}$ & $\begin{array}{l}\text { Instructor C } \\
\text { Instructor D }\end{array}$ \\
\hline Week 1 & Wallet activity. Form design teams. & $\begin{array}{l}\text { Shell Marshmallow Activity. Design } \\
\text { thinking } 1 . \text { Strategy generation. }\end{array}$ \\
\hline Week 2 & Human-centred design. & $\begin{array}{l}\text { Systems thinking } 1 \& 2 . \text { CAD (on- } \\
\text { going). Strategy selection. Organisation. }\end{array}$ \\
\hline Week 3 & Project management. & Design thinking $2 \& 3$. Tech topic 1 \\
\hline Week 4 & Identify stakeholders & $\begin{array}{l}\text { Tech topic } 2 \& 3 . \text { Design Heuristic } \\
\text { Cards / Mock ups. }\end{array}$ \\
\hline Week 5 & Develop specifications & Tech topic $4 \& 5$. Design presentation. \\
\hline Week 6 & Design Heuristics & Tech topic 6 \\
\hline Week 7 & Design review. & $\begin{array}{l}\text { Manufacturing Process } 1 . \\
\text { Manufacturing Plans. } \\
\text { Tech topic } 7 .\end{array}$ \\
\hline Week 8 & Proof of concept. Prototype & Tech topic 7 \\
\hline Week 9 & Design thinking & $\begin{array}{l}\text { Systems Thinking } 3 \& 4 \text {. Tech topic } 8 \text {. } \\
\text { Manufacturing Process } 2 \text {. }\end{array}$ \\
\hline Week 10-12 & $\begin{array}{l}\text { Design presentation/meeting. } \\
\text { Report }\end{array}$ & Design presentation /meeting. Report \\
\hline
\end{tabular}

Instructors reported that it was easy to perform the planning and preparation required to integrate the Design Heuristic tool into their classrooms. All four instructors planned the lesson details approximately a week in advance of their lesson. Approximately a week prior, during the weekly meeting, Instructors $\mathrm{C}$ and D discussed how the Design Heuristic tool would be implemented; for example, "We had a deeper conversation on how exactly we would like the students to use it" (Instructor C).

All the instructors noted that they watched the Design Heuristic video from the website at least once, and some instructors mentioned they transcribed the lesson. The video lesson appeared to 
be valuable and helpful in lesson preparation. This is highlighted by Instructor B's comments: "I really did find the video presentation to be one of the most helpful things... I had taken quite a few notes while I was going through the video..."

The instructors were free to adapt the Design Heuristics slides to suit their classes. This was highlighted in Instructor A's comments: "I loved the autonomy and freedom to kind of just take ownership... I didn't feel that I was constrained." Instructors said that they took notes from the video and recreated the slides. Each instructor then used their recreated slides as a guide during the lesson. For example, Instructor B commented that he "made a few minor changes on that [slides] where it seemed like it would be helpful, put notes together on PowerPoint presentation to remind me of what I was wanting to say." Table 5 outlines briefly the adaptations each instructor made to the slides.

Table 5: Adaptation of lesson resources

\begin{tabular}{|l|l|}
\hline Instructors & Lesson materials used \\
\hline Instructor A & $\begin{array}{l}\text { Used DH PPT layout. Applied the human-centered EPIC Design process model } \\
\text { in the course to demonstrate and guide students through the design process. }\end{array}$ \\
\hline Instructor B & $\begin{array}{l}\text { Used DH slides during exploring problem solutions. Watched and took notes on } \\
\text { the example slides; pulled out comments that were helpful; made some minor } \\
\text { changes to the slides; put notes together on the slides as a reminder of what to } \\
\text { say. Applied the human-centered EPIC Design process model in the course to } \\
\text { demonstrate and guide students through the design process. }\end{array}$ \\
\hline Instructor C & $\begin{array}{l}\text { Used few slides. Changed the slides to white background and black text; used a } \\
\text { card once in the demonstration to show how to think about using heuristics, but } \\
\text { did not directly address anything beyond the title of the card. }\end{array}$ \\
\hline Instructor D & $\begin{array}{l}\text { Used few slides. Changed the slides to white background and black text, } \\
\text { jumped right into the team of people who created the cards. Used similar slides } \\
\text { to Instructor C, but with a focus on Routine Design. }\end{array}$ \\
\hline
\end{tabular}

\section{During the DH lesson}

The instructional environment for the Design Heuristics implementation varied among the four instructors. Instructor A offered a lecture, while the three other instructors (B, C and D) conducted a lab session. The lecture and lab session for Instructors A and B were structured akin to the Design Heuristics lesson video resource. The lab sessions for Instructor C and D were more active, and provided less content on fewer slides ( 3 slides outlining common challenges in ideation, Design heuristics, and Design Heuristics cards). The lesson structure appeared to be guided by the slides for all four instructors. The following flow charts represent and highlight the lesson structures for each instructor (Figure 3-6). It should be noted that the flowcharts represent the progression of the lesson content rather than the duration of activities. For the four instructor's lesson flowcharts, corresponding activities between instructors have been portrayed in a vertical representation, where possible.

Design review
overview;
previous lesson


Figure 3: Instructor A's lesson flowchart

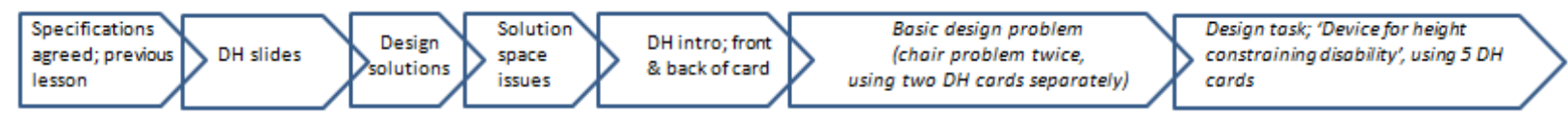

Figure 4: Instructor B's lesson flowchart

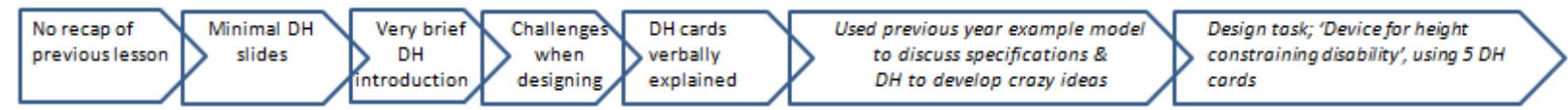

Figure 5: Instructor C's lesson flowchart

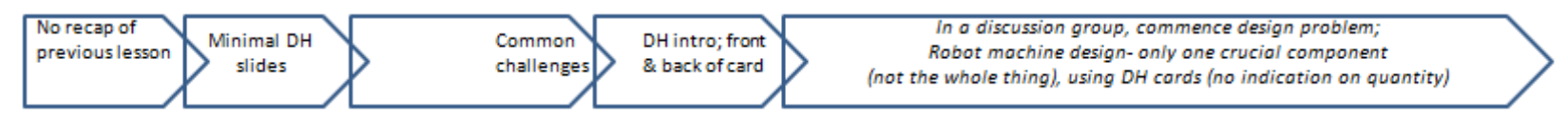

Figure 6: Instructor D’s lesson flowchart

\section{A. Pedagogical approaches}

As the flowcharts show, each instructor created their own lesson. Practice tasks for initiation design (Instructor B) and subcomponent design (Instructors C \& D) were the main activities for using the Design Heuristics tool. The design problem used to scaffold the Design Heuristics lesson was either a holistic task (Instructors A \& B) or subcomponent elements (Instructors C \& D). Instructor A's lesson was a lecture format, so a more time was spent on the background of the Design Heuristics tool. This provided students with a rationale and description of the research behind the Design Heuristics tool.

The length of the lesson presentation (before students began actively participating) ranged from 5 minutes (Instructor C) to 37 minutes (Instructor A). Instructor C highlighted the importance of adequate time for active learning for students: "I don't think it's worthwhile to just give it to the students for 10-15 minutes. I think you need to get it to the students for an hour or something and really let them go to work and kind of force them to keep coming up with ideas. ...though, you have to contextualize it to what they're doing."

\section{B. Introduction to Design Heuristics}

The introduction of Design Heuristics cards included a combination of the following steps:

- Holding a card while describing;

- Showing the PowerPoint slide while describing the card;

- Displaying sample cards on PowerPoint slides;

- Describing the front of the card initially, referring to the back of the card later in the lesson;

- Explaining front and back of card consecutively; and

- Introducing the back of the card after students practiced creating concepts using the front of the card (after 30-minutes).

The number of cards and the design problem context used by each instructor is outlined in Table 6. Instructors A and B provided practice with the Design Heuristics tool through short design 
tasks in an idea initiation context. Instructor A guided individual concept generation, initially using one heuristic card, and students progressed to the use of five heuristic cards; Instructor B had students practice with two, and provided sets of 10 cards to each student. Instructors C and D guided students to use the Design Heuristics tool for idea generation on an actual course project. As this project had progressed to concept refinement, the Design Heuristics tool was implemented within an idea development or component design context (the design of a critical component of their concept). Instructors C \& D did not specify the number of heuristics to be used during the lesson (though 1 card was provided to each student). However, Instructor D also highlighted the most relevant heuristic cards with respect to the course project for the students.

Table 6: Lesson variables

\begin{tabular}{|c|c|c|c|c|}
\hline Instructor & $\begin{array}{l}\text { Class size } \\
\text { (number of } \\
\text { students) }\end{array}$ & Lesson context & Problem & $\begin{array}{l}\text { Number of Design } \\
\text { Heuristics cards per } \\
\text { student }\end{array}$ \\
\hline \multirow[t]{2}{*}{$\mathrm{A}$} & \multirow[t]{2}{*}{$\sim 15$} & \multirow[t]{2}{*}{ Idea Initiation } & Design a chair & $\begin{array}{l}\text { Individually practiced } \\
\text { using front of } \mathrm{DH} \# 13\end{array}$ \\
\hline & & & $\begin{array}{l}\text { How to organize / } \\
\text { store books }\end{array}$ & $\begin{array}{l}\text { Share the cards, but } \\
\text { individually using } 5 \\
\text { cards. }\end{array}$ \\
\hline \multirow[t]{2}{*}{ B } & \multirow[t]{2}{*}{$\sim 7$} & \multirow[t]{2}{*}{ Idea Initiation } & Design a chair & $\begin{array}{l}\text { Individually practice } \\
\text { using front of DH\#76 } \\
\text { and DH\#26 }\end{array}$ \\
\hline & & & $\begin{array}{l}\text { Design an assistive } \\
\text { device for an } \\
\text { individual who is } \\
\text { height constrained } \\
\text { (short) }\end{array}$ & $\begin{array}{l}\text { Sets of } 10 \text { cards per } \\
\text { student. }\end{array}$ \\
\hline $\mathrm{C}$ & $\sim 20$ & $\begin{array}{l}\text { Idea } \\
\text { Development, } \\
\text { Component } \\
\text { Design }\end{array}$ & $\begin{array}{l}\text { Design the most } \\
\text { critical component } \\
\text { of your robot (RMP) }\end{array}$ & 1 heuristic per student. \\
\hline $\mathrm{D}$ & $\sim 20$ & $\begin{array}{l}\text { Idea } \\
\text { Development, } \\
\text { Component } \\
\text { Design }\end{array}$ & $\begin{array}{l}\text { Generate } \\
\text { /modify/brainstorm } \\
\text { the most critical } \\
\text { component of your } \\
\text { robot (RMP) }\end{array}$ & $\begin{array}{l}1 \text { heuristic per student. } \\
\text { Also advised about the } \\
\text { most relevant heuristic } \\
\text { cards (DH\#4, DH\#34, } \\
\text { DH\#36, DH\#42, } \\
\text { DH\#46, DH\#65, } \\
\text { DH\#75) }\end{array}$ \\
\hline
\end{tabular}

Other variations occurred in the presentation of the Design Heuristics, including:

- Individual use and through sharing / passing of Design Heuristics cards.

- Practice in using the Design Heuristics cards: One instructor (A) started by showing only the front of one DH card, and instructed students to practice designing based on this exposure. Afterwards, the students were introduced to the back of the card.

- Two instructors (A \& B) scaffolded practice through a short design problem (a 'chair design'), using one or two DH cards. Then these instructors asked students to design a 
'bookshelf for Habitat for Humanity' or a 'height constraining disability device', where 5 DH cards were used by each individual student.

- One instructor (D) carried out the practice use of the Design Heuristics cards via brainstorming discussion groups, however no ideas where recorded (written down).

- One instructor (C) used the Design Heuristics as an appraisal or decision making tool for the concepts generated by promoting students to consider 'how' certain elements of their refined designs would be feasible.

- One instructor (D) prescribed pre-selected cards which were specifically relevant to their task Add to existing product \# 4, Extend surface \#34, Fold \#36, Make components attachable / detachable \#42, Mimic natural mechanism \#46, Telescope \#65 and Utilize inner space \#75.

- One instructor (C) advised the use of Design Heuristics cards for designing a subcomponent of their design project.

- Instructor B included other design strategies in parallel to the integration of Design Heuristics, such as brainstorming, and user-centered design principles.

- One instructor (A) used an extrinsic motivation element: A prize valued at less than a dollar was offered for the most creative concept.

The variation in lesson structure across the courses highlights the flexibility of the cards. This was emphasized by Instructor A, who commented, "I didn't feel constrained... it's much more equitable than brainstorming. It has a lot of great features to that conceptual pool of design heuristics. "In addition, one instructor informed students that Design Heuristics can be used both for initial idea generation and refinement at later stages of the design process. Instructor $\mathrm{C}$ also expanded the use of the cards by having students design subcomponents: "Students were thinking about how they were going to attach the device, when the cards talk about components or modularizing or having something be able to be removable I think that definitely affected some of the teams in the way that they focused more on how it's going to attach." Instructors felt that these variations were effective in helping students generate multiple concepts.

\section{Challenges}

Some issues or questions about implementation emerged in both in the context of the Design Heuristic tool and the design process:

\section{Challenges implementing the Design Heuristics tool}

1. Student understanding of product examples provided on the cards: "The examples are good on the cards but still some students have a hard time relating to them so like you said changing the context somehow and giving them examples that have been used in the past. I think that's the biggest challenge" (Instructor C).

2. Timing or placement of the Design Heuristics tool among other design activities: "We didn't use them early on enough... there was some limitation because it was introduced after they were locked into a project"' (Instructor C).

3. Fixation on early design concepts: "Yeah, from week one, they were tempted to go off with an idea and say this is the best idea" (Instructor A); and "The biggest challenge that they had was 
that they had an idea set in their head already" (Instructor C). Instructor C consequently noticed how the Design Heuristics tool developed students' concepts: "I saw and heard their ideas change a lot after that [DH tool use], or I think maybe it reinforced some of their ideas, too. Some of their ideas became even more developed I think after that" (Instructor C).

\section{Challenges with respect to the design process}

1. Flexibility in concept generation with respect to the culture of engineering: "Because we are dealing with engineers, I think it's very hard for many of us to think outside of the box...they never look at other options" (Instructor D).

2. The mentor-instructor role in terms of voicing their own ideas vs. allowing students to generate ideas: "I try not to give to specific of examples or anything and just point out 1 or 2 cards...It's also really hard for me not to give them ideas" (Instructor C).

3. Traditional norms that challenge a developing design pedagogy: "there are some faculty that if it's not in the textbook they really won't give it solid credence... but I don't think they are more credible or more scholarly than using a repertoire of conceptual tools and resources kind of anchored in the design community" (Instructor A).

\section{Reflections after the Design Heuristics session}

The reflections were extracted from individual post-interviews with the instructors after their lesson. While some themes from 'During DH session' (based on the videotapes of instructors' classes) may reoccur in the 'Reflections after DH session,' these findings represent two different data sources.

\section{A. How DH transformed their instruction (pedagogical style)}

All four instructors noted that Design Heuristics transformed their pedagogical style to teach idea generation in the context of establishing a nurturing environment of trust. The heuristic resource video prompted two instructors to comment on creating an environment where students were comfortable sharing their ideas. For example, "I think that's absolutely so important, beyond just design heuristics to encourage talking and dialogue" (Instructor A). Instructor B felt that it was important to "make a real effort on affirming whatever ideas they were coming up with. I thought I saw her [the instructor on the DH video] doing that in her presentation and it seemed to really help open up the discussion, help them feel more comfortable in sharing". The development of a nurturing environment, through building trust was expressed by one instructor; "The freshman have taken me quite seriously on the Design Heuristics and then in systematically making decisions. We built a good trust I think in that class. In the junior class we have built a good trust" (Instructor A).

The timing or placement for introducing the Design Heuristics tool within the design process was emphasized repeatedly by instructors. For example, "[If] could do anything differently, I think maybe this could be done a little bit earlier" (Instructor D). There was also a comment about needing to present technical information before concept generation and vice versa. A question was raised whether existing concepts should be generated before the heuristic use: "Instead, if 
they were generating the concept using the card, which I think is the correct way to use it. Then I think it will be a lot better and I think the students will have a better connection of the two. I think though, what I realized, to talk about the heuristics card, they still had to have some sort of an idea of their concept. So it can't just be taught on its own, it has to come between something and then another thing. I don't know how to exactly explain it, but if there were just one lecture on design heuristics card without actually talking about different types of concept generation, or give them a context of what this card is trying to accomplish, then I don't think it would be as effective" (Instructor D).

\section{B. Changes in student activity}

Teaching approaches to the design process varied, ranging from 'not so rigid about following design', 'design is the sequence', 'design as an evolving process', 'service oriented, it's always been human centered design,' to 'service learning.' Overall, the instructors emphasized that the Design Heuristics tool was more supportive of concept generation than other approaches. For example, Instructor D noted, "[We] teach about how to select a concept ... but not necessarily how to generate concepts, or deal with having to make changes and Design Heuristics was kind of the gap there to be filled." Part of the success for Instructor D was the ability to emphasize the usefulness and empirical evidence of the heuristic tool; "This is actually credible...this actually is useful."

One instructor requested more practice briefs to facilitate students' initial use of the Design Heuristics tool; "Giving a variety of options or suggested activities would be helpful so to be able to pick from those. Maybe some that are specific, like the chair, the solar oven, and some that are more general ideas, think project your students are engaged in right now, have them work through this on that specific problem" (Instructor B).

\section{Discussion}

This study offers evidence of the successes and challenges instructors face in implementing the Design Heuristics tool in engineering courses. Participants included educators at multiple universities who did not all teach the same course or level of student. Thus, understanding their successes and struggles can benefit those who want to implement the tools into their own unique contexts. In the following paragraphs, we summarize the thematic results in the context of before, during and after the Design Heuristic session, and propose preliminary guidelines for concept generation instruction.

\section{Before Design Heuristics session}

The instructors' prior teaching experiences with Design Heuristics were varied; however, all reported ease of use and implementation. This was primarily due to the support of the Design Heuristic video including an example lesson. The preparations carried out by all instructors were collaborative. Two instructors reported a preference for implementing the Design Heuristics tool even earlier in the class project. The adaptation of the Design Heuristic resources (the PowerPoint slides) required minimal changes for all instructors. The slides provided key 
touchstones and scaffolded the design activity for effective instruction. A summary of the guidelines before implementing a DH session in a class is outlined in Table 7.

Table 7: Prior to a DH session guidelines

\begin{tabular}{|c|c|}
\hline First time teaching with DHs & $\begin{array}{l}\text { - } \quad \text { You do not need to be an expert } \\
\text { - } \quad \text { Develop a familiarity with Design Heuristics } \\
\text { - } \quad \text { Practice with problem brief for course. }\end{array}$ \\
\hline Preparations & $\begin{array}{l}\text { - } \\
\text { - } \text { Access the free DH lesson resources online. } \\
\text { - Develop awareness of the importance of concept } \\
\text { generation. } \\
\text { - Develop a familiarity with other concept generation } \\
\text { strategies that could be used in parallel with Design } \\
\text { Heuristics. } \\
\text { - Consider integrating Design Heuristics within a project } \\
\text { setting to ensure effective timing and use within the } \\
\text { design process. } \\
\text { Ensure hands-on participation of students in Design } \\
\text { Heuristics use. }\end{array}$ \\
\hline $\begin{array}{l}\text { Consider use of DH in multiple } \\
\text { stages in the design process }\end{array}$ & $\begin{array}{l}\text { - The DH tool allows for varied approaches and tasks } \\
\text { including 'design as an evolving process', 'service } \\
\text { oriented, human centered design', to 'service learning'. } \\
\text { - The DH tool supports ideation during initial concept } \\
\text { generation, subcomponent design, transformational } \\
\text { design, and in individual or teaming settings. }\end{array}$ \\
\hline
\end{tabular}

During Design Heuristics session

Each instructor demonstrated the effectiveness of using the $\mathrm{DH}$ tool by allowing students to engage in active learning. No instructor applied the heuristic cards in a team setting; instead, all instructors opted to have their students use the heuristic cards individually. Instructor D included a discussion group, and further exploration of the DH tool within teams may be advantageous, especially after students have generated initial ideas. The concept generation lessons offered in the courses varied in terms of introductory time ( 5 to 37 minutes), problem statements provided, and the quantity of heuristic cards allocated to students (from 1 to 10 cards). This variation highlights the flexibility of the DH tool for different contexts and instructor preferences. The two contexts selected (initial ideation and subcomponent design) for implementation of Design Heuristics were effective, and students successfully generated multiple concepts. A summary of the guidelines for during a DH session are outlined in Table 8.

Table 8: During a DH session guidelines

\begin{tabular}{|l|l|}
\hline Pedagogical approaches & $\begin{array}{l}\text { Lesson variations and structures are customizable } \\
\bullet\end{array}$ \\
& $\begin{array}{l}\text { Practice tasks are recommended to scaffold student } \\
\text { understanding of the DH tool use }\end{array}$ \\
& Ideation tasks can be structured for idea initiation, \\
\hline
\end{tabular}




\begin{tabular}{|c|c|}
\hline & $\begin{array}{l}\text { subcomponent design, or evaluation } \\
\text { - Lessons can be a lecture format providing a theoretical } \\
\text { understanding for the Design Heuristics tool, which can } \\
\text { develop student's appreciation of the tool development and } \\
\text { validity } \\
\text { - The time frame for concept generation can vary, though } \\
\text { early in the conceptual design phase is recommended } \\
\text { - Ensure adequate time for active learning by students }\end{array}$ \\
\hline Introduction to $\mathrm{DH}$ & $\begin{array}{l}\text { - Describe the heuristic cards' features (title, number, abstract } \\
\text { image, description, innovative product examples) } \\
\text { - Describe the front of the card initially, followed by the back } \\
\text { of the card } \\
\text { - Explain front and back of card consecutively or separately } \\
\text { (between a simple practice task) } \\
\text { - Students first individually generate concepts using the cards } \\
\text { - Allow adequate time to practice using the Design heuristic } \\
\text { cards }\end{array}$ \\
\hline $\begin{array}{l}\text { Additional recommendations } \\
\text { on } \mathrm{DH} \text { tool use }\end{array}$ & $\begin{array}{l}\text { The number of cards provided can vary from one to five in } \\
\text { a subsequent practice task. In addition, specific cards } \\
\text { relating to a specific project can be prescribed. The rotation } \\
\text { of cards among students can expose students to a range of } \\
\text { heuristics } \\
\text { - DH cards can be used indivdually or together to form a new } \\
\text { concept. Alternatively, one card could be used to generate } \\
\text { multiple concepts } \\
\text { - The DH tool can be used in parallel to other ideation } \\
\text { strategies } \\
\text { - The DH tool can be used to appraise ideas or as a decision } \\
\text { making tool for concepts generated } \\
\text { - Aprize" can be offered to promote an increase in number } \\
\text { of concepts generated }\end{array}$ \\
\hline $\begin{array}{l}\text { To overcome identified } \\
\text { challenges }\end{array}$ & $\begin{array}{l}\text { In addition to the product examples provided on the cards, } \\
\text { encourage students to think about the graphic image of the } \\
\text { heuristic } \\
\text { - Use the DH tool early in concept generation to promote } \\
\text { fluency in ideation, thus reducing fixation. } \\
\text { - Develop student awareness about the flexibility of the DH } \\
\text { tool for initial concept generation, subcomponent design } \\
\text { and other stages of the design process. } \\
\text { - Broaden student's awareness of the importance of idea } \\
\text { - } \text { Auantity, diversity, elaboration, creativity, and practicality. } \\
\text { - Allow sufficient time to practice use with the tool. }\end{array}$ \\
\hline
\end{tabular}

After the Design Heuristics session 
All instructors noted how Design Heuristics transformed their pedagogical style in teaching about idea generation. Instructors expressed a pedagogical understanding of how to generate and make changes to concepts. The instructor's reflections are captured in the recommended practices in Table 9.

Table 9: Recommended practices identified after a DH session

\begin{tabular}{|l|l|}
\hline To transform instruction & $\begin{array}{l}\text { Nurture a classroom environment where students are } \\
\text { comfortable sharing their ideas }\end{array}$ \\
$\bullet$ & $\begin{array}{l}\text { Have students take an active role in learning } \\
\text { Establish a nurturing environment of trust. This promotes } \\
\text { students comfort in sharing their ideas. }\end{array}$ \\
$\qquad \begin{array}{l}\text { Affirm initial ideas, thus reducing early evaluation of } \\
\text { concepts. }\end{array}$ \\
\hline To change student activity & $\begin{array}{l}\text { Place the Design Heuristic tool within the design process } \\
\text { to suit the needs of specific projects (e.g., capstone } \\
\text { design projects). }\end{array}$ \\
$\qquad \begin{array}{l}\text { Present research evidence about the Design Heuristics } \\
\text { tool. }\end{array}$ \\
$\qquad \begin{array}{l}\text { Add practice briefs to acquaint students with the Design } \\
\text { Heuristics tool. } \\
\text { Allow students to voice their ideas to build confidence } \\
\text { Ask students to generate existing concepts before using } \\
\text { Design Heuristics. This allows students to present their } \\
\text { initial concepts, which can then be further developed, } \\
\text { synthesized, elaborated with the support of the Design } \\
\text { Heuristics tool. }\end{array}$ \\
\hline
\end{tabular}

Timing or placement of the Design Heuristics instruction appeared to be the most dominant issue. Further exploration of heuristic use across a design process is important for identifying places within the design process where the tool is most useful. Breaking the technical dominance of engineering instruction was highlighted, which was credited to the flexibility added by the Design Heuristics tool. Allowing students to discover and develop concepts through Design Heuristics is very closely related to providing familiar product examples. While we want instruction to foster students' concept generation abilities, there is also a need to develop student autonomy and confidence during concept generation.

To support integration of the Design Heuristics tool into engineering courses, we developed three separate lessons that use the tool to support 1) Idea Initiation- developing an idea from scratch, 2) Idea Development- iterating on existing solutions and 3) Component Design- decomposing the problem into functions, generating ideas for functions, and recomposing the ideas into a complete design $^{25,36}$. The lessons also include optional variations in which students can work individually as well as with teams. The lesson versions include videotaped example lessons and PowerPoint presentations for instructors to choose what fits best within their class contexts.

\section{Conclusion}


This study contributes to our understanding of the Design Heuristics tool from the instructors' perspectives during their implementation of a course lesson. All four instructors in this study reported great ease of use in terms of learning the heuristic tool and adapting the tool to their particular course context. Both novice and experienced instructors reported fairly quick and easy lesson preparation, course implementation and outcomes facilitated by web-based example lessons. This investigation revealed flexibility in the use of the Design Heuristics tool in instruction, and easy customization based on instructors' preferences. The practices observed across instructors in this study can be used to support engineering instructors who wish to incorporate idea generation using Design Heuristics into their existing courses.

\section{References}

1. Daly, S. R., Yilmaz, S., Christian, J. L., Seifert, C. M., \& Gonzalez, R. (2012). Design Heuristics in engineering concept generation. Journal of Engineering Education, 101(4), 601-629.

2. Daly, S. R., Yilmaz, S., Christian, J. L., Seifert, C. M., \& Gonzalez, R. (2014). 77 Design Heuristics. H.S. Fogler and S. LeBlanc (eds.), Strategies for Creative Problem Solving 3rd Ed. New York, NY: Prentice Hall.

3. Kramer, J., Daly, S. R., Yilmaz, S., \& Seifert, C. M. (2014, June). A case-study analysis of Design Heuristics in an upper-level cross-disciplinary design course. In Proceedings of the ASEE Annual Conference, Indianapolis, IN: ASEE.

4. Brophy, Dennis R. Comparing the Attributes, Activities, and Performance of Divergent, Convergent, and Combination Thinkers. Creativity Research Journal 2001, 13 (3-4): 439-55.

5. Liu, Y.-C., A. Chakrabarti, and T. Bligh. Towards an 'ideal'Approach for Concept Generation. Design Studies 2003, 24 (4), 341-55

6. Yilmaz, S., Daly, S. R., Seifert, C. M., \& Gonzalez, R. (2014, June). Design Heuristics as a tool to improve innovation. In Proceedings of the ASEE Annual Conference, Indianapolis, IN: ASEE.

7. Kramer, J. Daly, S.R., Yilmaz, S., Seifert, C.M., \& Gonzalez, R. (2015). Investigating the Impacts of Design Heuristics on Idea Initiation and Development, Advances in Engineering Education, 4(4).

8. Ahmed, S., K.M. Wallace, and L.T.M. Blessing, Understanding the differences between how novice and experienced designers approach design tasks. Research in Engineering Design, 2003, 14(1), 1-11.

9. Ball, L.J., J. Evans, and I. Dennis, Cognitive processes in engineering design: A longitudinal study. Ergonomics, 1994, 37(11), 1753-1786.

10. Cross, N. Design cognition: Results from protocol and other empirical studies of design activity. In Design Knowing and Learning: Cognition in Design Education. Chapter 5, Pages 79-103, 2001.

11. Ullman, D.G., T. Dietterich, and L. Stauffer. A model of the mechanical design process based on empirical data. Artificial Intelligence in Engineering Design and Manufacturing. 1988, 2(1), 33-52.

12. Grasso, D., Burkins, M. B., Helble, J. J., \& Martinelli, D. Dispelling the myths of holistic engineering. 2008, PE Magazine.

13. Klukken, P. G., Parsons, J. R., \& Columbus, P. J. The creative experience in engineering practice: Implications for engineering education. Journal of Engineering Education, 1997, 86(2), 133-138.

14. Pappas, J., \& Pappas, E. Creative thinking, creative problem-solving, and inventive design in the engineering curriculum: A review. In Proceedings of the 2003 American Society for Engineering Education Annual Conference.

15. Richards, L. G. (1998). Stimulating creativity: teaching engineers to be innovators. In Frontiers in Education Conference, 1998. FIE'98. 28th Annual. 3,1034-1039. IEEE.

16. Wang, L., Shen, W., Xie, H., Neelamkavil, J., \& Pardasani, A. Collaborative conceptual design-state of the art and future trends. Computer-Aided Design 2002, 34 (13), 981-99

17. Jansson, D. G., \& Smith, S. M. Design fixation. Design Studies, 1991, 12(1), 3-11.

18. Purcell, A. T. \& Gero, J. S. Design and other types of fixation, Design Studies, 1996, 17(4), $363-383$. 
19. Henderson, C., Beach, A., \& Finkelstein, N. Facilitating change in undergraduate STEM instructional practices: An analytic review of the literature. Journal of Research in Science Teaching, 2011, 48(8), 952984.

20. Henderson, C. Promoting instructional change in new faculty: An evaluation of the physics and astronomy new faculty workshop. American Journal of Physics, 2008, 76(2), 179-187.

21. Dancy, M. \& Henderson, C. Pedagogical Practices and Instructional Change of Physics Faculty. American Journal of Physics, Physics, 2010, 78 (10), 1056-1063.

22. Perkins, D., Creativity's camel: The role of analogy in invention, in Creative Thought, T. Ward, S. Smith, and J. Vaid, Editors. American Psychological Association: Washington, DC. 1997, 523-528.

23. Osborn, A., Applied imagination: Principles and procedures of creative problem-solving. 1957, NY: Scribner.

24. Finke, R.A., T.B. Ward, and S.M. Smith, Creative cognition: Theory, research, and applications. 1992, Cambridge, MA: The MIT Press.

25. Design Heuristics. (2012). Retrieved from www.designheuristics.com

26. Yilmaz, S., Seifert, C. M., \& Gonzalez, R. (2010). Cognitive heuristics in design: Instructional strategies to increase creativity in idea generation. Journal of Artificial Intelligence for Engineering Design, Analysis, and Manufacturing, 24(3), 335-355.

27. Yilmaz, S., Daly, S. R., Seifert, C. M., \& Gonzalez, R. (2010, September). Design Heuristics in ideation across engineering and industrial design domains. In C. Boks, C. McMahon, W. Ion, and B. Parkinson (eds.), In Proceedings of the 12th International Conference on Engineering and Product Design Education: When Design Education and Design Research Meet, Trondheim, Norway: EPDE.

28. Yilmaz, S., Daly, S. R., Seifert, C. M., \& Gonzalez, R. (2010, July). A comparison of cognitive heuristic use between engineers and industrial designers. In: J. S. Gero ed. Proceedings of the 4th International Conference on Design Computing and Cognition, pp. 3-22, Stuttgart, Germany: DCC.

29. de Bono, E., Six thinking hats. 1999: Back Bay Books.

30. Allen, M., Morphological creativity. 1962, New Jersey: Prentice-Hall.

31. Zwicky, F., Discovery, invention, research through the morphological approach. 1969, New York, NY: Macmillan.

32. Eberle, B., Scamper. 1995, Waco, Texas: Prufrock.

33. Gordon, W.J.J., Synectics. 1961, New York: Harper \& Row.

34. Altshuller, G., Creativity as an exact science. 1984, New York, NY: Gordon and Breach.

35. Altshuller, G., 40 Principles: TRIZ keys to technical innovation. 1997, Worcester, MA: Technical Innovation Center, Inc.

36. Yilmaz, S., Daly, S., Seifert, C., \& Gonzalez, R. (2015). How Do Designers Generate New Ideas? Design Heuristics across two disciplines. Design Science, 1, e4. DOI: http://dx.doi.org/10.1017/dsj.2015.4

37. Yilmaz, S., Seifert, C. M., \& Gonzalez, R. (2010, July). Cognitive heuristics in design. In: J. S. Gero ed. Proceedings of the 4th International Conference on Design Computing and Cognition: pp. 35-54, Stuttgart, Germany: DCC.

38. Christian, J. L., Daly, S. R., Yilmaz, S., Seifert, C. M., \& Gonzalez, R. (2012, June). Design Heuristics support two modes of idea generation: Initiating ideas and transitioning among concepts. In Proceedings of the ASEE Annual Conference, San Antonio, TX: ASEE.

39. Yilmaz, S., \& Seifert, C. M. (2011). Creativity through Design Heuristics: A case study of expert product design. Design Studies, 32(4), 384-415.

40. Daly, S. R., Christian, J. L., Yilmaz, S., Seifert, C. M, \& Gonzalez, R. (2011). Assessing Design Heuristics for idea generation in an introductory engineering course. International Journal of Engineering Education, 28(2), 463-473.

41. Yilmaz, S., Daly, S. R., Seifert, C. M., \& Gonzalez, R. (2014, May). Design Heuristics as a tool for innovation. Conference on Psychology of Design: Creating Consumer Desire. Ann Arbor, MI: Society for Advertising \& Consumer Psychology.

42. Yilmaz, S., Daly, S. R., Christian, J. L., Seifert, C. M., \& Gonzalez, R. (2012, May) How do Design Heuristics affect outcomes? In: M. M. Andreasen, H. Birkhofer, S. J. Culley, U. Lindemann, and D. Marjanovic (Eds.), In Proceedings of 12th International Design Conference (DESIGN), pp. 1195-1204. Dubrovnik, Croatia: DESIGN.

43. Yilmaz, S., Daly, S. R., Seifert, C. M., \& Gonzalez, R. (2013, September). Comparison of design approaches between engineers and industrial designers. In Proceedings of International Conference of Engineering and Product Design Education, Dublin, Ireland: EPDE. 
44. Lincoln, YS. \& Guba, EG. Naturalistic Inquiry. 1985, Newbury Park, CA: Sage Publications.

45. Ilevbare, I. M., Probert, D., \& Phaal, R. (2013). A review of TRIZ, and its benefits and challenges in practice. Technovation, 33(2), 30-37. 